http://dx.doi.org/10.1175/BAMS-D-11-00128.1

(c) 2012 American Meteorological Society

\title{
Phenomenal sea states and swell from a North Atlantic Storm in February 2011: a comprehensive analysis
}

\author{
Jennifer A. Hanafin ${ }^{a}$, Yves Quilfen ${ }^{a}$, Fabrice Ardhuin ${ }^{a}$, Joseph Sienkiewicz ${ }^{b}$, Pierre Queffeulou, \\ Mathias Obrebski ${ }^{\mathrm{a}}$, Bertrand Chapron ${ }^{\mathrm{a}}$, Nicolas Reul ${ }^{\mathrm{a}}$, Fabrice Collard ${ }^{\mathrm{c}}$, David Corman ${ }^{\mathrm{d}}$, \\ Eduardo B. de Azevedo ${ }^{\mathrm{e}}$, Doug Vandemark ${ }^{\mathrm{f}}$, and Eleonore Stutzmann ${ }^{\mathrm{g}}$
}

\footnotetext{
${ }^{a}$ Laboratoire d'Océanographie Spatiale, Plouzané, France

${ }^{b}$ NOAA/NWS/NCEP/Ocean Prediction Center, Camp Springs, Maryland

${ }^{\mathrm{c}}$ CLS-Brest, Brest Technopole, Plouzané, France

d Service Hydrographique et Océanographique de la Marine, Brest, France

e Universidade dos Açores, CLIMAAT/MacSIMAR, Angra do Heroísmo, Azores, Portugal

${ }^{\dagger}$ Coastal Ocean Observing Center, University of New Hampshire, Durham, New Hampshire

${ }^{g}$ Departement de Sismologie, Institut de Physique du Globe de Paris, Sorbonne Paris-Cité, Paris, France
}

*: Corresponding author : Jennifer A. Hanafin, email address : jenny.hanafin@ifremer.fr 
In the North Atlantic there are more than ten extra-tropical storms every year with hurricane-force winds (Figure 1). Observing the dynamics and effects of these storms is a particular challenge

30 because in situ observations are scarce and opportunities to apply and validate remote sensing techniques for wind speeds above hurricane force and for phenomenal sea states are rare. We show here that a suite of data from different sources, a combination which may not be typical in forecasting environments, can give a remarkably coherent characterisation of an extreme storm event and associated wave fields. In February 2011 the North Atlantic storm Quirin produced the

35 ideal conditions to illustrate this synergetic approach.

Phenomenal seas, defined by the World Meteorological Organization (WMO) as having a significant wave height $\left(\mathrm{H}_{\mathrm{s}}\right)$ larger than $14 \mathrm{~m}^{1}$, were observed over the North Atlantic Ocean in February 2011. Three intense atmospheric low pressure systems followed the typical storm track

40 (seen in figure 1), from the north-eastern United States to the ocean area south-east of Greenland during the first half of the month. The storm Quirin rapidly followed the third of these, but took a more southerly route, depicted in the track overlaid on figure 1. The phenomenal sea states generated by this storm were observed by satellites, and produced extremely long swells along the western coast of Europe, which were observed by wave buoys and seismic stations. The ocean

45 conditions between the storm source and swell landfall can be determined using numerical wave models and a state-of-the-art model, WAVEWATCH-III ${ }^{\circledR}$ (WW3), was used to reproduce both the extreme sea states and subsequent swell fields generated by this storm.

\section{Extratropical storm Quirin: the synoptic situation}

50 This system was the last of four deep lows with hurricane-force winds that developed in close succession over the northern Atlantic. National Oceanographic and Atmospheric Administration

1 The term "phenomenal" is one level of the Douglas scale which is recommended for use by the WMO, see http://www.wmo.int/pages/prog/amp/mmop/faq.html 
(NOAA) Ocean Prediction Center (OPC) synoptic analysis charts (Figure 2) show that on the $13^{\text {th }}$ February, Quirin was south of Newfoundland, while the storm Paolini was still very active with hurricane-force winds blowing south of Greenland. By $00 \mathrm{Z}$ on the $14^{\text {th }}$, Quirin had moved to the northeast at a speed of $23.6 \mathrm{~m} / \mathrm{s}$ and had rapidly intensified by $34 \mathrm{hPa}$ in 24 hours, well above the threshold for 'bombogenesis' (Sanders and Gyakum 1980).

Figure 3 presents the National Centers for Environmental Prediction (NCEP) wind analyses for the $13^{\text {th }}$ and $14^{\text {th }}$ at 12 hour intervals for comparison with observations from the Advanced

60 SCATterometer (ASCAT) on board MetOp and from the Indian Oceansat-2 scatterometer. Two altimeter tracks (black lines) crossed the storm when it was close to its maximum intensity. The NCEP wind analysis gives a maximum wind speed of $27.9 \mathrm{~m} / \mathrm{s}$ at $00 \mathrm{Z}$ on the $13^{\text {th }}$, slightly above the $25.1 \mathrm{~m} / \mathrm{s}$ from ASCAT and indicates that Quirin had reached hurricane-force intensity by 09Z (not shown). The ASCAT pass at 12:44 confirms this and maps out a storm-force wind envelope similar 65 to that of the NCEP field at 12Z, although it is rotated around the storm center, possibly due to the time difference. The maximum NCEP wind speed of $35.1 \mathrm{~m} / \mathrm{s}$ is very close to the $35.3 \mathrm{~m} / \mathrm{s}$ estimated from ASCAT at this time, probably as ASCAT winds are assimilated in this analysis. At $00 \mathrm{Z}$ on the $14^{\text {th }}$, the size and shape of the hurricane-force winds are still visually in close agreement, with the maximum NCEP wind speed now lower than the $39.8 \mathrm{~m} / \mathrm{s}$ ASCAT value by only $1.6 \mathrm{~m} / \mathrm{s}$. A 70 couple of hours later, a complementary Oceansat-2 scatterometer pass (bottom right panel of figure 3) shows a wide area with hurricane-force winds reaching up to $44.7 \mathrm{~m} / \mathrm{s}$.

These maximum wind estimates are difficult to validate. As frequently reported in the Mariners Weather Log (MWL) publications, the ASCAT values are likely to be underestimated at high wind 75 speeds and the reported maximum values for Quirin possibly suffer large errors (see supplementary material, data section, for less cursory discussion and Quilfen et al. (2010) for a review of the 
satellite measurements' techniques and limitations). More direct intercomparison between different sources may help to further identify the useful high wind scales. Satellite altimeters provide high resolution $(\sim 5 \mathrm{~km})$ estimates of $\mathrm{H}_{\mathrm{s}}$ but also of high wind speeds that have been calibrated by comparison with the QuikScat winds (Quilfen et al. 2011). QuikScat data have long been a standard for operational forecasters and QuikScat high wind estimates are more accurate than the ASCAT ones (see supplementary information). Altimeters are thus likely to bring useful information although measurements are performed along a narrow ground track. The bottom panels in Figure 4 display the wind speed from different sources (NCEP, satellite scatterometers, altimeters,

85 radiometers) interpolated to the Envisat and Jason-2 altimeter tracks shown in figure 3. Beyond hurricane-force, the estimated maximum winds can differ significantly, partly because of the different resolution of the datasets, but the general agreement of all sensors up to hurricane-force winds is remarkable. It shows that information is available to estimate the scales over which Quirin winds reached gale, storm, and hurricane-force, given a good knowledge of the sensors limitations.

90 Although the ASCAT and altimeter coverage is insufficient to completely map the storm, the bottom panels in Figure 4 indicate that the NCEP winds underestimate the storm and hurricane-force radii as well as the maximum values for the available passes.

Figure 4, middle panels, shows $H_{\mathrm{s}}$ values recorded by satellite altimeters on February $13^{\text {th }}$ and $14^{\text {th }}$, 95 together with the values predicted by the WW3 numerical model. Wave heights in excess of $10 \mathrm{~m}$ were generated by Paolini over a large part of the Atlantic Ocean, north of $50^{\circ} \mathrm{N}$ on the $13^{\text {th }}$. Later on the same day, the Envisat altimeter measured a maximum $\mathrm{H}_{\mathrm{s}}$ value of $18.1 \mathrm{~m}$ under Quirin's hurricane-force winds. The day after, Quirin had generated phenomenal seas over a $533 \mathrm{~km}$ long track with a maximum of $20.1 \mathrm{~m}$ reported by the Jason-2 altimeter. Such exceptional values were 100 emphasized in the 2011 December issue of MWL: "Altimetry data from 1100 UTC on the 14th (Figure 13 ) reveal seas as high as $66 \mathrm{ft}(20.1 \mathrm{~m})$, the highest the author has seen in this type of 
imagery” (Bancroft, 2011).

As for the wind observations, these extreme $\mathrm{H}_{\mathrm{s}}$ values are outside the validated range of altimeter $\mathrm{H}_{\mathrm{s}}$ measurements (see supplementary material for discussion). In spite of the lack of an absolute accuracy estimate of the extreme values, an analysis of the entire Jason- 1 and Jason- $2 \mathrm{H}_{\mathrm{s}}$ data set (January 2002 to December 2011) showed that Quirin produced the largest individual $1 \mathrm{~Hz}$ measurement $(20.1 \mathrm{~m})$. Another indicator of sea state is the average $\mathrm{H}_{\mathrm{s}}$ of all measurements greater than $14 \mathrm{~m}$ along a satellite pass in the vicinity of a storm, and Quirin also produced the highest

110 along-track average $(16.2 \mathrm{~m}$ over $533 \mathrm{~km})$ over this 9-year period.

The wave field generated by Quirin was hindcast with WW3 forced by ECMWF and NCEP wind analysis (see supplementary information for details). The middle panels in Figure 4 show the $\mathrm{H}_{\mathrm{s}}$ along the satellite track when using European Centre for Medium-Range Weather Forecasts

115 (ECMWF, red) and NCEP (green) analyses winds. It can be seen that the model performs well both at generating the high $\mathrm{H}_{\mathrm{s}}$ observed by satellites and at reproducing these phenomenal seas over such large scales. The NCEP values were increased by $10 \%$ to better match the satellite-based wind measurements, which resulted in better prediction of the extreme $\mathrm{H}_{\mathrm{s}}$ values by the wave model (blue).

\section{Storm swell observations and modelling}

Complementary satellite information on the swell emerging from the storm was provided by wave mode images from Envisat's Advanced Synthetic Aperture Radar (SAR). The SAR clearly revealed a peak wavelength of $700 \mathrm{~m}$ (corresponding to a period of $22 \mathrm{~s}$ ) emerging from the region of the

125 storm at $23: 23$ on $14^{\text {th }}$ February (Figure 5 ) near $58.5^{\circ} \mathrm{N}, 29.5^{\circ} \mathrm{W}$. 
Additional spectral information is available from buoys, located from the Azores along western Europe as far north as Scotland. Figure 5 (top panel) shows that the $\mathrm{H}_{\mathrm{s}}$ observed by the buoys is considerably reduced from the high open ocean values, because of swell dispersion and dissipation

130 (Ardhuin et al. 2009), while all of the maximum peak periods ( $\mathrm{Tp}_{\max }$ ) observed were above $20 \mathrm{~s}$. Time series of the peak periods (not shown) show very clearly the arrival of $T \mathrm{p}_{\max }$ at each wave buoy, first at the Azores with waves of period 21s observed approximately 24 hours after the winds generated by Quirin reached hurricane-force. Over the next 24 hours, $T p_{\max }$ was observed arriving at many buoys along the western coast of Europe and at the Canary Islands, reaching over $23 \mathrm{~s}$ off the west coast of France and up to 25s to the west of Scotland and north of Spain.

Land-based seismometers can provide a very useful complement to buoy observations as the background seismic noise, mostly generated by ocean waves, can propagate from a localised storm source area over distances of thousands of kilometers. Non-linear interaction between waves having similar frequencies and moving in almost opposite directions generates seismic waves at twice the wave frequency, producing a peak in the seismic spectrum, typically at 0.08-0.3 Hz (Bernard 1941, see supplementary information for more detail).

The bottom panel of figure 5 shows the 3 hour median of the vertical ground displacement variance 145 of several seismic stations around the North Atlantic, from February $14^{\text {th }}$ to $16^{\text {th }}$. These were filtered to keep only the energy corresponding to swell with periods longer than 20 s. On February $14^{\text {th }}$, a peak was observed at station CMLA in the Azores, about 12 hours before the arrival of $T p_{\max }$ observed by the wave buoy at the same location. The seismic stations in Scotland, Iceland and Greenland observed an increase in seismic noise starting after midday on the $14^{\text {th }}$, with peaks 150 occurring on the $15^{\text {th }}$ for the stations based on continental Europe. The maximum level was reached around noon on the $15^{\text {th }}$, coinciding with the arrival of peak periods at the wave buoys along the 
coasts of western Europe (top panel, figure 5).

In the seismic record of the CMLA station for February $14^{\text {th }}$ and the European stations in the evening of February $15^{\text {th }}$, the strong noise level in the double-frequency band (see supplementary material) is accompanied by a lower energy peak below $0.05 \mathrm{~Hz}$. This indicates that the source is at least partly associated with waves reaching the shore (Hasselmann 1963). On the contrary, the local maxima recorded in Iceland and Scotland, at $00 \mathrm{Z}$ to $03 \mathrm{Z}$ on February $15^{\text {th }}$ are not associated with a significant low frequency noise and are probably due to the strong rotation of winds and waves inside Quirin. Indeed, our wave model predicts that a very intense noise source was centered at $54^{\circ} \mathrm{N} 28^{\circ} \mathrm{W}$ at that time.

In the top panel of figure 5 the peak periods of the swell field output from the WW3 model, forced by NCEP winds increased by $10 \%$ in magnitude, are shown, as discussed in the previous section.

165 With this correction, the maximum wave heights at the peak of the storm are within $5 \%$ of the observations, while the $\mathrm{Tp}_{\max }$ reach 20 to $24 \mathrm{~s}$ (figure 5) as the longer waves reached European shores. The peak periods, the timing of the swell arrival, and the associated wave heights are in very good agreement with the buoy and seismic station observations around the basin, showing that the current generation of wave models are capable of both reproducing the observed phenomenal sea

170 states and accurately predicting the subsequent propagation of the swell field.

\section{Quirin in historical perspective}

Numerical wave models can be used to provide a full space-time coverage of the global sea state and although the wave heights they produce are generally biased low for phenomenal seas, the

175 random error is relatively small, typically under 10\% (Ardhuin et al. 2010). Here we use a consistent model hindcast forced by Climate Forecast System Reanalysis winds (Saha et al. 2010), 
from 1994 to 2010, along with NCEP analysis winds for 2011. Over a 12 year period (1999-2011), the maximum $\mathrm{H}_{\mathrm{s}}$ value obtained for Quirin put the storm in $13^{\text {th }}$ position globally, and $3^{\text {rd }}$ over the North Atlantic, being about $2 \mathrm{~m}$ less than the record $\mathrm{H}_{\mathrm{s}}$ produced by Tropical Cyclone Yasi which made landfall in Northeast Australia on February 2, 2011.

Because these wave model estimates are as uncertain as the wind fields used as input, the long timeseries of seismic data available at several stations around the Atlantic Basin offer an interesting independent observation. As analysis of the low frequency seismic noise provides information on

185 the longest periods generated by a given storm, it may be tentatively used to quantify the relative importance of major events such as Quirin. For the years 1996 to 2011, only seven storms produced an rms noise larger than $0.25 \mu \mathrm{m}$ in the 0.08 to $0.1 \mathrm{~Hz}$ band at station CMLA (Azores), whereas Quirin registered $1 \mu \mathrm{m}$. This work confirms that the low frequency noise level is a good indicator of storm intensity, as proposed by Ebeling and Stein (2011) for the investigation of hurricanes. The interpretation of seismic noise records is complicated by the fact that the noise level observed by a seismometer depends on the storm trajectory as well as the intensity. Further work will focus on the analysis of historical wave hindcast and seismic records to investigate the potential of seismic measurements for storm intensity analysis.

\section{Discussion}

Following Kahma and Calkoen (1992), and assuming that the usual fetch laws apply at high wind speeds, we expect that peak periods of $23 \mathrm{~s}$ can be formed by wind speeds exceeding $40 \mathrm{~m} / \mathrm{s}$ over at least two days or even stronger winds over a shorter duration. This crude analysis suggests that either the wind was in reality higher than the maximum winds given by numerical weather analyses 200 and scatterometers over a longer time period, or some mechanism greatly enhanced the transfer of energy from wind to waves over a shorter period of time. 
Apart from the wind strength, several conditions may have allowed exceptional growth of the wind sea at this time. The hurricane-force winds associated with Quirin blew over a sea already roughened by Paolini, which can be seen in the top panels of figure 4, which may have enabled a faster growth for the wind sea. Numerical wave modelling tests suggest that, in fact, the sea state before Quirin had little effect on the magnitude of the wave heights or periods.

A more likely explanation for the extreme sea state is a resonance phenomenon, which occurs when

210 the storm displacement speed roughly equals the group speed of the dominant waves, so the waves are continuously fed by the wind input. The Quirin storm speed at approximately $20 \mathrm{~m} / \mathrm{s}$ between the $13^{\text {th }}$ at $12 \mathrm{Z}$ and the $14^{\text {th }}$ at $00 \mathrm{Z}$ (table 1 ) corresponds to the group velocity of waves with a period of about $26 \mathrm{~s}$ in deep water, a value close to the largest wave periods observed near the coasts. The same phenomenon explained all of the very high sea states reported in the North

215 Atlantic (Cardone et al. 2011; Holliday et al. 2006)

The North Atlantic extra-tropical storm Quirin produced, on $14^{\text {th }}$ February 2011, wave heights that are expected to occur only about once a year over the globe, according to our hindcast results. Waves from the center of the storm radiated as swell with very long periods, from 20 to $25 \mathrm{~s}$, and were recorded around the northern and eastern Atlantic basin. Although the maximum values for wind and wave estimates are difficult to validate, the evidence presented in this study gives credence to the observed scales over which hurricane-force winds and sea state developed. Once the forcing wind field was adjusted to better match the satellite observations, a numerical wave model performed very well in reproducing the local sea state and swell field around the basin, given the extreme input conditions. 
We are encouraged by these results to report that our ability to both model and observe extreme wave events has improved greatly in recent years, while a novel look at century-old seismic records will help refine the climatology of such rare events. 


\section{References}

Ardhuin, F., B. Chapron, and F. Collard, 2009: Observation of swell dissipation across oceans. Geophys. Res. Lett., 36, L06607, doi:10.1029/2008GL037030.

Ardhuin, F. and Coauthors, 2010: Semi-empirical dissipation source functions for wind-wave models: part I, definition, calibration and validation. J. Phys. Oceanogr., 40, 1917-1941.

Bancroft, G., 2011: Marine Weather Review - North Atlantic Area, January to June 2011. Mariner's Weather Log, December 2011 55, 13-26

Bernard, P., 1941: Sur certaines proprietes de la boule etudiées a l'aide des enregistrements seismographiques. Bull. Inst. Oceanogr. Monaco, 800, 1-19.

Cardone, V. J., A. T. Cox, M. A. Morrone, and V. R. Swail, 2011: Global distribution and associated synoptic climatology of very extreme sea states (VESS). Proceedings, 12th Int. Workshop of Wave Hindcasting and Forecasting, Hawaii, USA.

Ebeling, C. W., and S. Stein, 2011: Seismological Identification and Characterization of a Large Hurricane. Bulletin of the Seismological Society of America, 101, 399-403, doi:10.1785/0120100175.

Hasselmann, K., 1963: A statistical analysis of the generation of microseisms. Rev. of Geophys., 1, $177-210$

Holliday, N. P., M. J. Yelland, R. Pascal, V. R. Swail, P. K. Taylor, C. R. Griffiths, and E. Kent, 2006: Were extreme waves in the Rockall Trough the largest ever recorded? Geophys. Res. Lett., 33, L05613, doi:10.1029/2005GL025238.

Kahma, K. K. and C. J. Calkoen, 1992: Reconciling discrepancies in the observed growth of windgenerated waves, J. Phys. Oceanogr., 22, 1389-1405.

Quilfen, Y., B. Chapron, and J. Tournadre, 2010: Satellite microwave surface observations in tropical cyclones, Mon. Weather Rev., 138, 421-437, doi:10.1175/2009MWR3040.1.

Quilfen, Y., D. Vandemark, B. Chapron, H. Feng, and J. Sienkiewicz, 2011: Estimating Gale to 
Hurricane Force Winds Using the Satellite Altimeter. J. Atmos. Ocean Technol., 28, 453458.

Saha, S. and Coauthors, 2010: The NCEP Climate Forecast System Reanalysis. Bull. Amer. Meterol. Soc., 91, 1015-1057.

Sanders, F., and J. R. Gyakum, 1980: Synoptic-Dynamic Climatology of the "Bomb." Monthly Weather Review, 108, 1589-1606, doi:10.1175/1520-0493. 


\section{Figure Captions}

Figure 1. Annual average frequency of the low pressure centers with hurricane-force winds based

235 on the NOAA OPC 6-hourly surface pressure analyses and QuikSCAT winds. Average was calculated based on data from September though May 2002-2009. The track of Quirin at 6-hourly intervals from $00 \mathrm{Z}$ on $13^{\text {th }}$ February till $18 \mathrm{Z}$ on $14^{\text {th }}$ February is overplotted. The size of the circle symbol at each time step reflects the surface area of winds $\geq 24.5 \mathrm{~m} / \mathrm{s}$ and the colour represents the maximum wind speed, see table 1 for details.

Figure 2. NOAA OPC synoptic analysis charts for $00 \mathrm{Z}$ on the $13^{\text {th }}$ (left) and on the $14^{\text {th }}$ February 2011 (right). On the $13^{\text {th }}$, Quirin was near $42 \mathrm{~N} 60 \mathrm{~W}$ at $984 \mathrm{hPa}$ and expected to track northeast (arrow) and intensify to hurricane force (DVLPG HURCN FORCE label) while Paolini (HURCN

245 FORCE label) was southeast of Greenland. By $00 \mathrm{Z}$ on the $14^{\text {th }}$ Quirin had intensified to $950 \mathrm{hPa}$ with hurricane-force winds and moved to $50.5 \mathrm{~N} 38 \mathrm{~W}$.

Figure 3. Top: NCEP wind analyses every 12 hours at synoptic times starting February $13^{\text {th }} 2011$ at 00Z (left), ending February $14^{\text {th }} 2011$ at $12 \mathrm{Z}$ (right). Two storms are active on the $13^{\text {th }}$, Paolini southeast of Greenland and Quirin traveling south of Newfoundland.

Bottom: Scatterometer winds available for that time period: ASCAT winds (three left panels) from passes within an hour of the above corresponding panel; and Oceansat-2 winds (right panel) at $25501: 52$ UTC on the $14^{\text {th }}$ for comparison with the $3^{\text {rd }}$ ASCAT overpass. Thick black lines show the paths of the two altimeters which crossed the area of storm-force winds, Envisat at $\sim 00 \mathrm{Z}$ and Jason2 at $\sim 12 \mathrm{Z}$ on the $14^{\text {th }}$. NCEP and scatterometer times and the maximum wind speed (Vmax ) in the 
Quirin storm are indicated in each panel title. Contours of storm force winds (cyan, V $\geq 24.5 \mathrm{~m} / \mathrm{s}$ ) and of hurricane-force winds (magenta, $\mathrm{V} \geq 32.7 \mathrm{~m} / \mathrm{s}$ ) are included to aid visualisation of the storm 260 intensity.

Figure 4. Top: altimeter $\mathrm{H}_{\mathrm{s}}$ measured by 4 altimeters (Jason-1, Jason-2, ERS-2 and Envisat) on February $13^{\text {th }}$ (left panel) and February $14^{\text {th }} 2011$ (right panel). The black square in the left (right) 265 panel indicates the location of the most extreme sea states measured during these two days by the Envisat (Jason-2) altimeter, respectively.

Middle: Focus on the altimeter (black) $\mathrm{H}_{\mathrm{s}}$ values estimated along the Envisat (left) and Jason-2 (right) tracks shown in figure 3 and indicated by the squares above, and computed from the WW3 270 model forced by ECMWF (red), NCEP (green) and NCEP+10\% (blue) winds. A running average has been applied to the altimeter data $(\sim 5 \mathrm{~km}$ resolution) to better match the resolution of the WW3 model $\left(0.5^{\circ}\right)$

Bottom: Wind speed from different sources interpolated on the same Envisat (left) and Jason-2

275 (right) altimeter tracks. For both panels, black (green) lines give the altimeter (NCEP) wind speed. For the left (right) panel, the dashed red line gives the ASCAT scatterometer (Jason-2 radiometer) wind speed. On the left panel, the blue line gives the Oceansat- 2 wind speed. All estimates have been computed at the spatial resolution of the NCEP fields. The dashed blue lines show the storm force $(\mathrm{V} \geq 24.5 \mathrm{~m} / \mathrm{s})$ and hurricane-force $(\mathrm{V} \geq 32.7 \mathrm{~m} / \mathrm{s})$ wind thresholds. A running average was 280 again applied to the altimeter data to better match the resolution of the other data sources $(\sim 25 \mathrm{~km})$. 
Figure 5. Top: Peak periods of the swell field: as calculated by WW3; from SAR observations; from wave buoy data; and from seismic buoy data. The background shows the output from the model at

$28512 \mathrm{Z}$ on the $15^{\text {th }}$, as the longest swells were encroaching on the west coast of Scotland. The square symbols represent the wave buoy data, the size of the symbol signifying the $\mathrm{H}_{\mathrm{s}}$ at the time of the maximum peak period observed and the color signifying the value of the peak period at this time. Beside each symbol is printed the time of arrival of the maximum peak period at each buoy. The circle gives the location of the SAR observations and diamond symbols represent the seismic 290 stations, also colored according to the peak periods observed.

Bottom: Time series of the 3 hour median of the vertical ground displacement variance averaged over 20 minutes, from several stations around the North Atlantic, from February $14^{\text {th }}$ to $17^{\text {th }}$. A timeseries of $\mathrm{H}_{\mathrm{s}}$ from a buoy (OLERON) located off the west coast of France is also shown. 


\section{Tables}

Table 1. Characteristics of Quirin based on NCEP analysis $0.5^{\circ} \mathrm{x} 0.5^{\circ}$ wind field. The storm-force area refers to the area with winds greater than $24.5 \mathrm{~m} / \mathrm{s}$.

\begin{tabular}{|c|c|c|c|c|c|c|}
\hline Date & Time & $\begin{array}{l}\text { Longitude } \\
\qquad\left({ }^{\circ} \mathbf{W}\right)\end{array}$ & $\begin{array}{l}\text { Latitude } \\
\left({ }^{\circ} \mathrm{N}\right)\end{array}$ & $\begin{array}{l}V_{\max } \\
(\mathrm{m} / \mathrm{s})\end{array}$ & $\begin{array}{c}\text { Storm-force } \\
\text { area }\left(10^{5} \mathrm{~km}^{2}\right)\end{array}$ & $\begin{array}{c}\text { Storm translation } \\
\text { speed }(\mathrm{m} / \mathrm{s})\end{array}$ \\
\hline $13 / 02$ & $00 Z$ & 60.5 & 39 & 27.93 & 1.12 & \\
\hline $13 / 02$ & $06 Z$ & 54.5 & 41 & 31.45 & 1.63 & 25.8 \\
\hline $13 / 02$ & $12 Z$ & 47.5 & 43.5 & 35.14 & 2.78 & 29.6 \\
\hline $13 / 02$ & $18 Z$ & 41.5 & 46 & 34.62 & 3.83 & 25.42 \\
\hline $14 / 02$ & $00 \mathrm{Z}$ & 37.5 & 47 & 38.34 & 5.09 & 15.08 \\
\hline $14 / 02$ & $06 Z$ & 34.5 & 48 & 33.46 & 4.34 & 11.63 \\
\hline $14 / 02$ & $12 Z$ & 31.5 & 49.5 & 32.82 & 4.38 & 12.78 \\
\hline $14 / 02$ & $18 Z$ & 30.5 & 51 & 30.6 & 3.36 & 8.39 \\
\hline
\end{tabular}




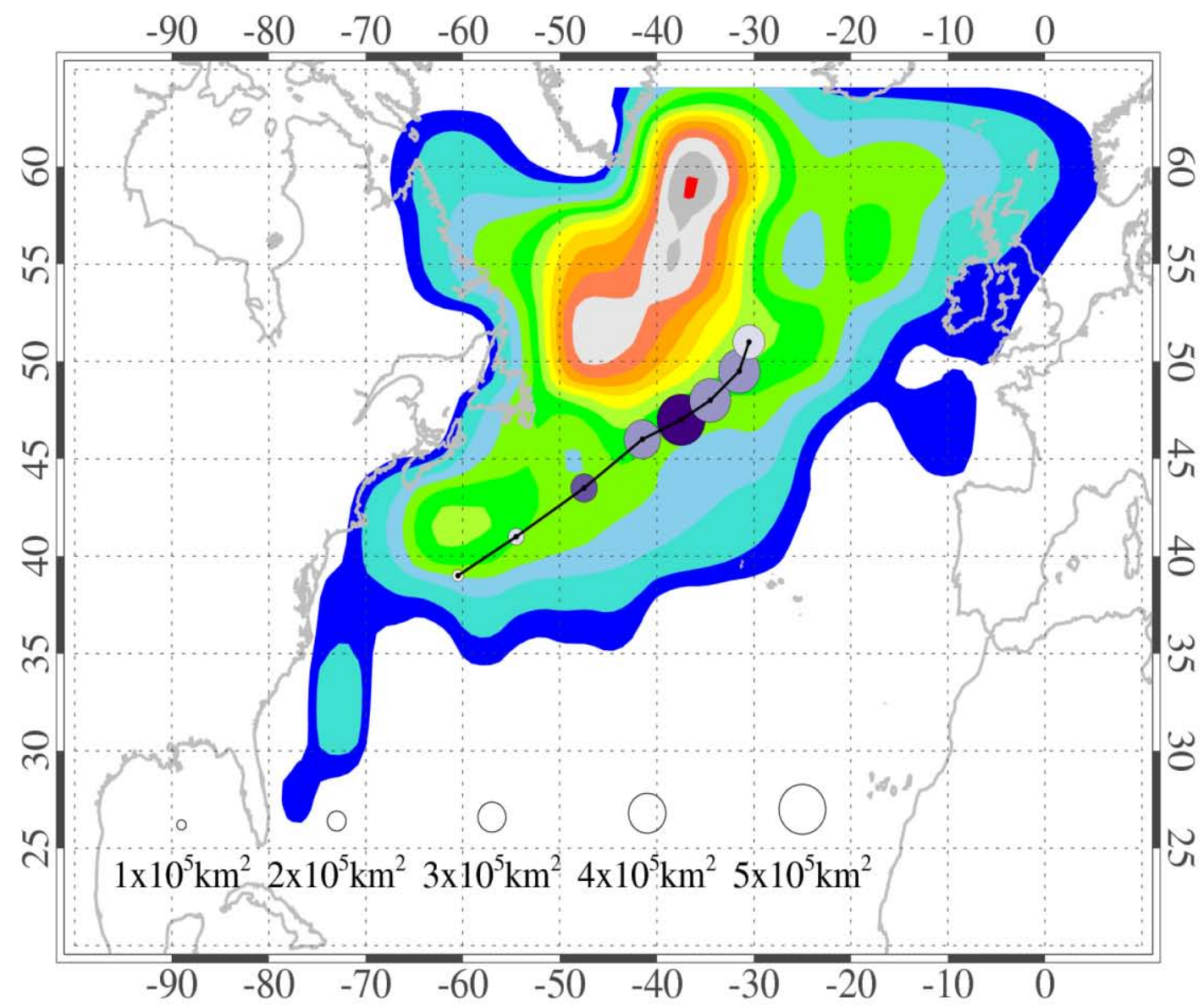

7-year annual average number of hurricane-force cyclones

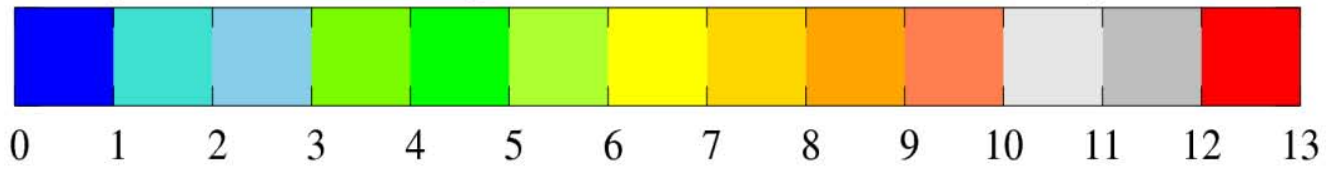

Maximum wind speed $(\mathrm{m} / \mathrm{s})$

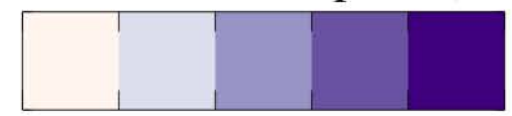

$\begin{array}{llllll}27.5 & 30.0 & 32.5 & 35.0 & 37.5 & 40.0\end{array}$

Figure 1. Annual average frequency of the low pressure centers with hurricane-force winds based on the NOAA OPC 6-hourly surface pressure analyses and QuikSCAT winds. Average was 
310 calculated based on data from September though May 2002-2009. The track of Quirin at 6-hourly intervals from $00 \mathrm{Z}$ on $13^{\text {th }}$ February till $18 \mathrm{Z}$ on $14^{\text {th }}$ February is overplotted. The size of the circle symbol at each time step reflects the surface area of winds $\geq 24.5 \mathrm{~m} / \mathrm{s}$ and the colour represents the maximum wind speed, see table 1 for details. 


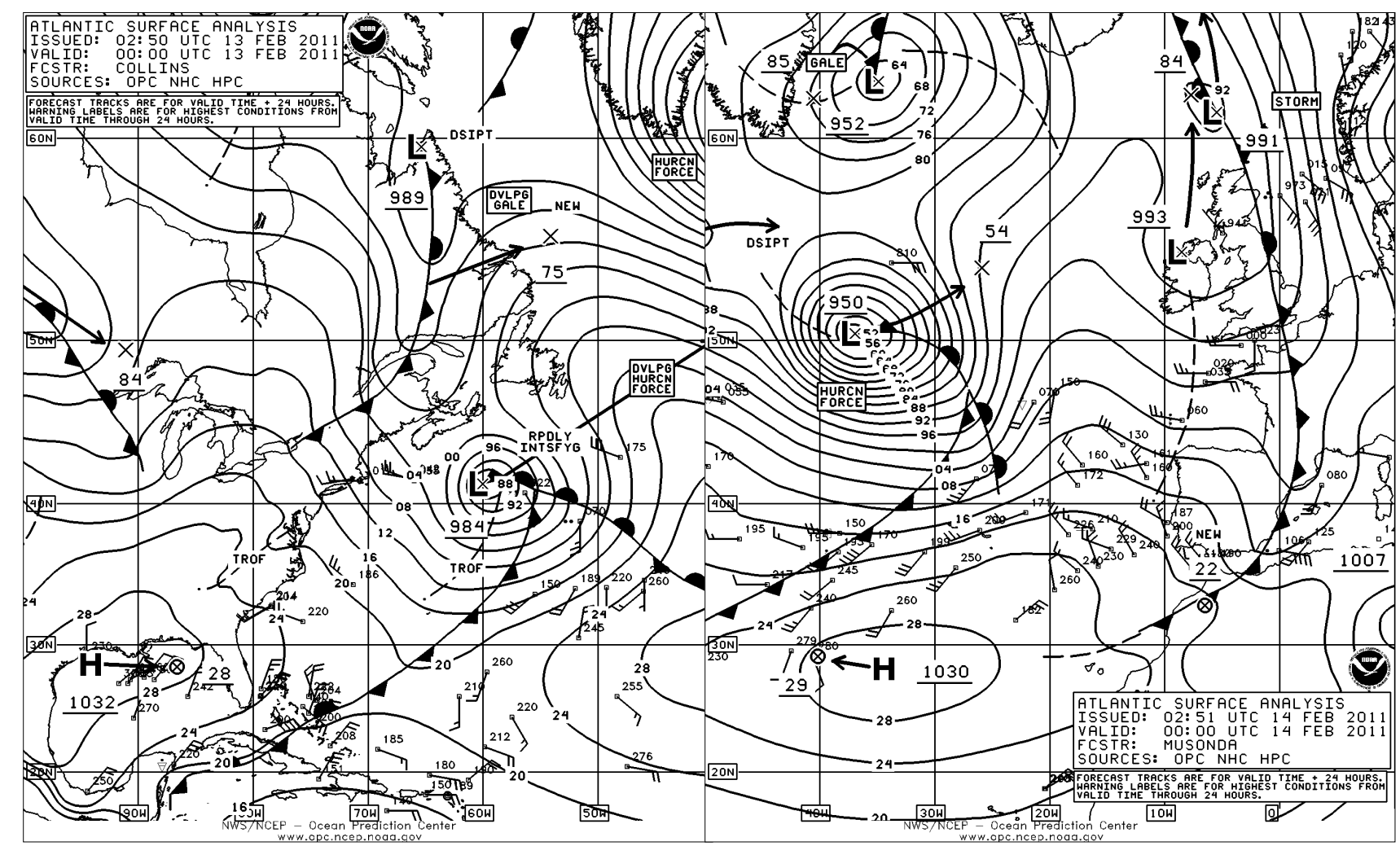

315

Figure 2. NOAA OPC synoptic analysis charts for $00 \mathrm{Z}$ on the $13^{\text {th }}$ (left) and on the $14^{\text {th }}$ February 2011 (right). On the $13^{\text {th }}$, Quirin was near $42 \mathrm{~N} 60 \mathrm{~W}$ at $984 \mathrm{hPa}$ and expected to track northeast (arrow) and intensify to hurricane force (DVLPG HURCN FORCE label) while Paolini (HURCN FORCE label) was southeast of Greenland. By 00Z on the $14^{\text {th }}$ Quirin had intensified to $950 \mathrm{hPa}$ with hurricane-force winds and moved to $50.5 \mathrm{~N} 38 \mathrm{~W}$. 


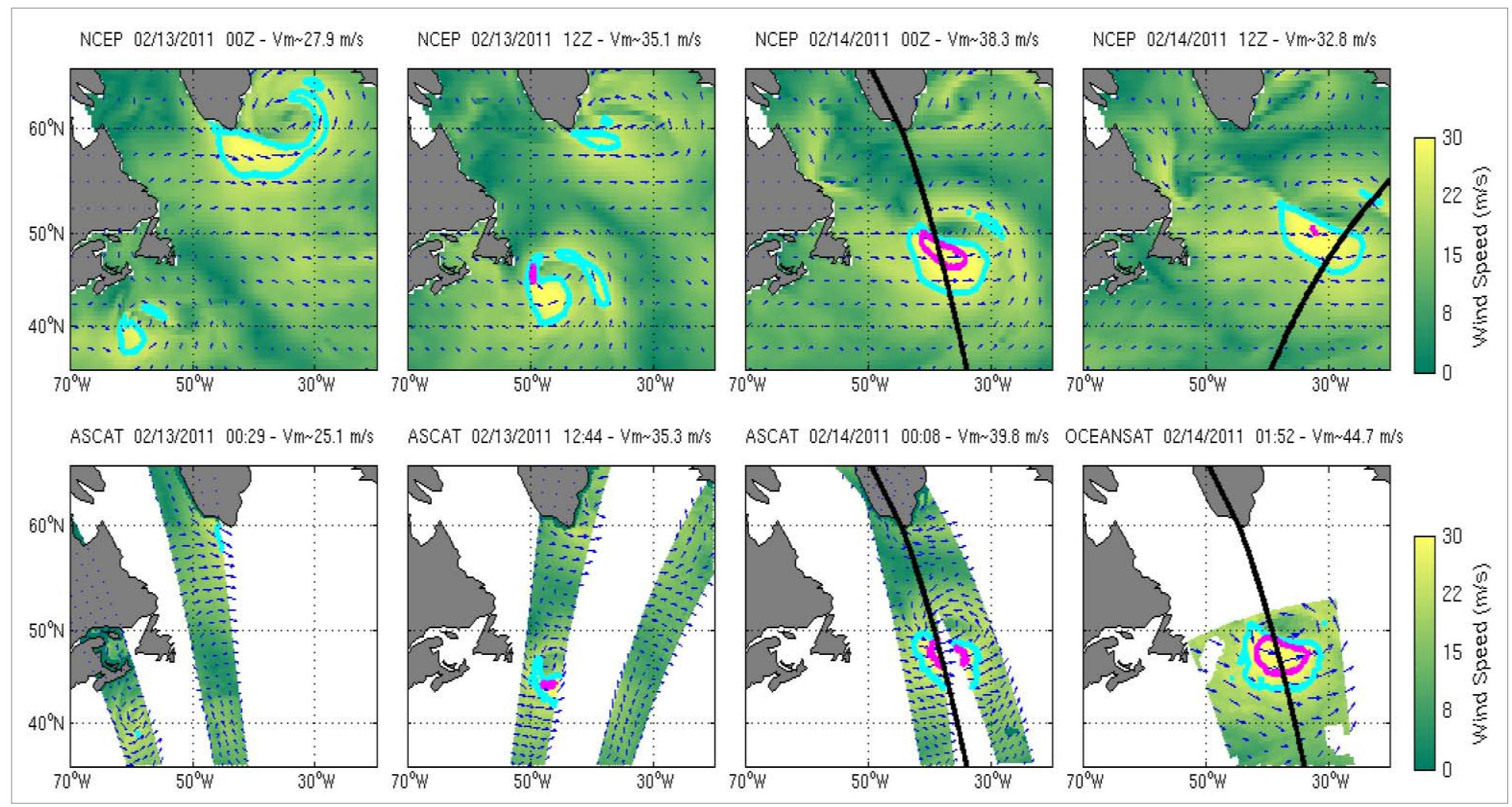

Figure 3. Top: NCEP wind analyses every 12 hours at synoptic times starting February $13^{\text {th }} 2011$ at $00 \mathrm{Z}$ (left), ending February $14^{\text {th }} 2011$ at $12 \mathrm{Z}$ (right). Two storms are active on the $13^{\text {th }}$, Paolini

330 southeast of Greenland and Quirin traveling south of Newfoundland.

Bottom: Scatterometer winds available for that time period: ASCAT winds (three left panels) from passes within an hour of the above corresponding panel; and Oceansat-2 winds (right panel) at 01:52 UTC on the $14^{\text {th }}$ for comparison with the $3^{\text {rd }}$ ASCAT overpass. Thick black lines show the

335 paths of the two altimeters which crossed the area of storm-force winds, Envisat at $\sim 00 \mathrm{Z}$ and Jason2 at $\sim 12 \mathrm{Z}$ on the $14^{\text {th }}$. NCEP and scatterometer times and the maximum wind speed (Vmax ) in the Quirin storm are indicated in each panel title. Contours of storm force winds (cyan, V $\geq 24.5 \mathrm{~m} / \mathrm{s}$ ) and of hurricane-force winds (magenta, $\mathrm{V} \geq 32.7 \mathrm{~m} / \mathrm{s}$ ) are included to aid visualisation of the storm intensity. 

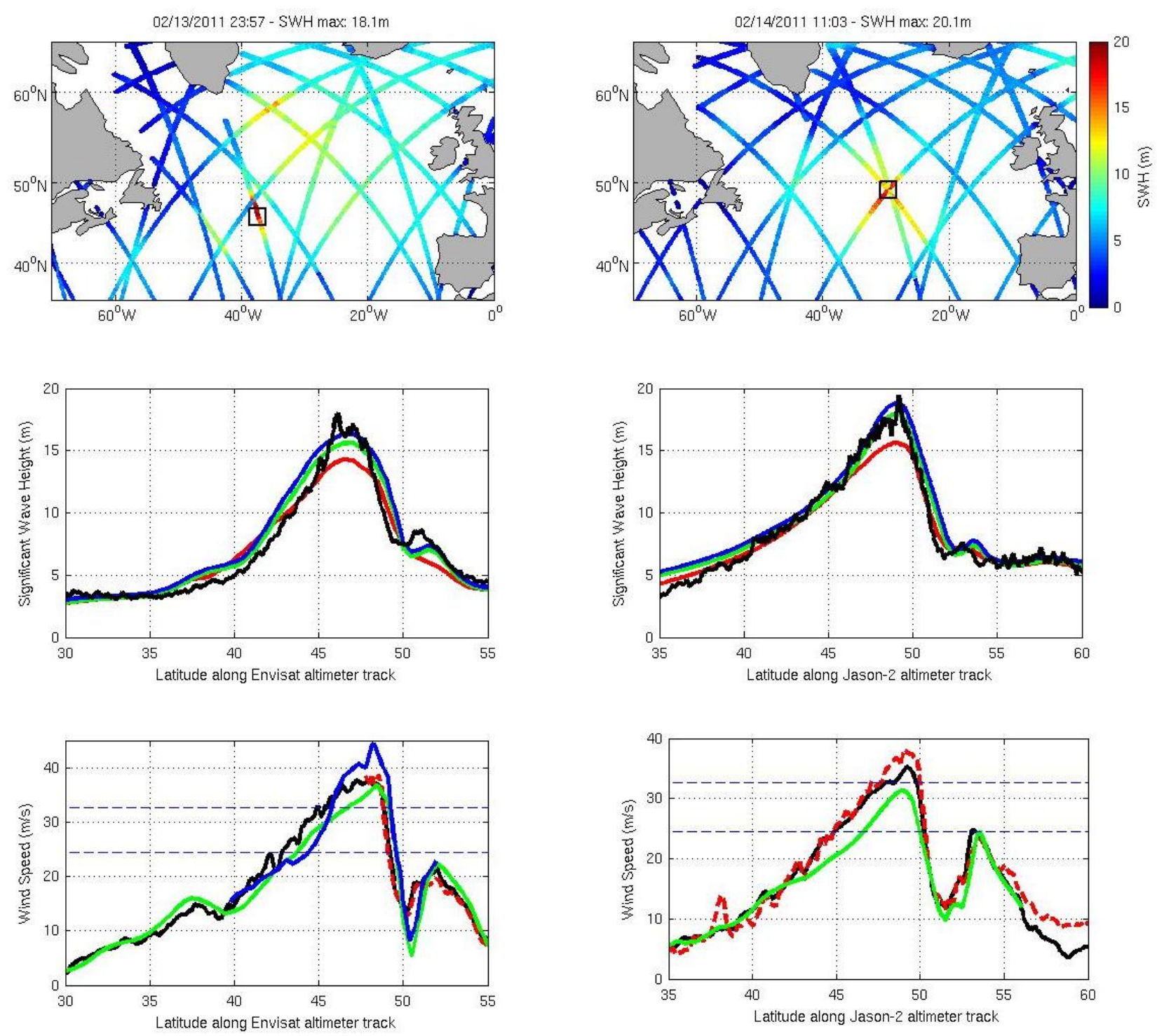

Figure 4. Top: altimeter $\mathrm{H}_{\mathrm{s}}$ measured by 4 altimeters (Jason-1, Jason-2, ERS-2 and Envisat) on February $13^{\text {th }}$ (left panel) and February $14^{\text {th }} 2011$ (right panel). The black square in the left (right) panel indicates the location of the most extreme sea states measured during these two days by the 345 Envisat (Jason-2) altimeter, respectively. 
Middle: Focus on the altimeter (black) $\mathrm{H}_{\mathrm{s}}$ values estimated along the Envisat (left) and Jason-2 (right) tracks shown in figure 3 and indicated by the squares above, and computed from the WW3 model forced by ECMWF (red), NCEP (green) and NCEP $+10 \%$ (blue) winds. A running average has been applied to the altimeter data $(\sim 5 \mathrm{~km}$ resolution) to better match the resolution of the WW3 model $\left(0.5^{\circ}\right)$

Bottom: Wind speed from different sources interpolated on the same Envisat (left) and Jason-2 (right) altimeter tracks. For both panels, black (green) lines give the altimeter (NCEP) wind speed.

355 For the left (right) panel, the dashed red line gives the ASCAT scatterometer (Jason-2 radiometer) wind speed. On the left panel, the blue line gives the Oceansat- 2 wind speed. All estimates have been computed at the spatial resolution of the NCEP fields. The dashed blue lines show the storm force $(\mathrm{V} \geq 24.5 \mathrm{~m} / \mathrm{s})$ and hurricane-force $(\mathrm{V} \geq 32.7 \mathrm{~m} / \mathrm{s})$ wind thresholds. A running average was again applied to the altimeter data to better match the resolution of the other data sources $(\sim 25 \mathrm{~km})$. 


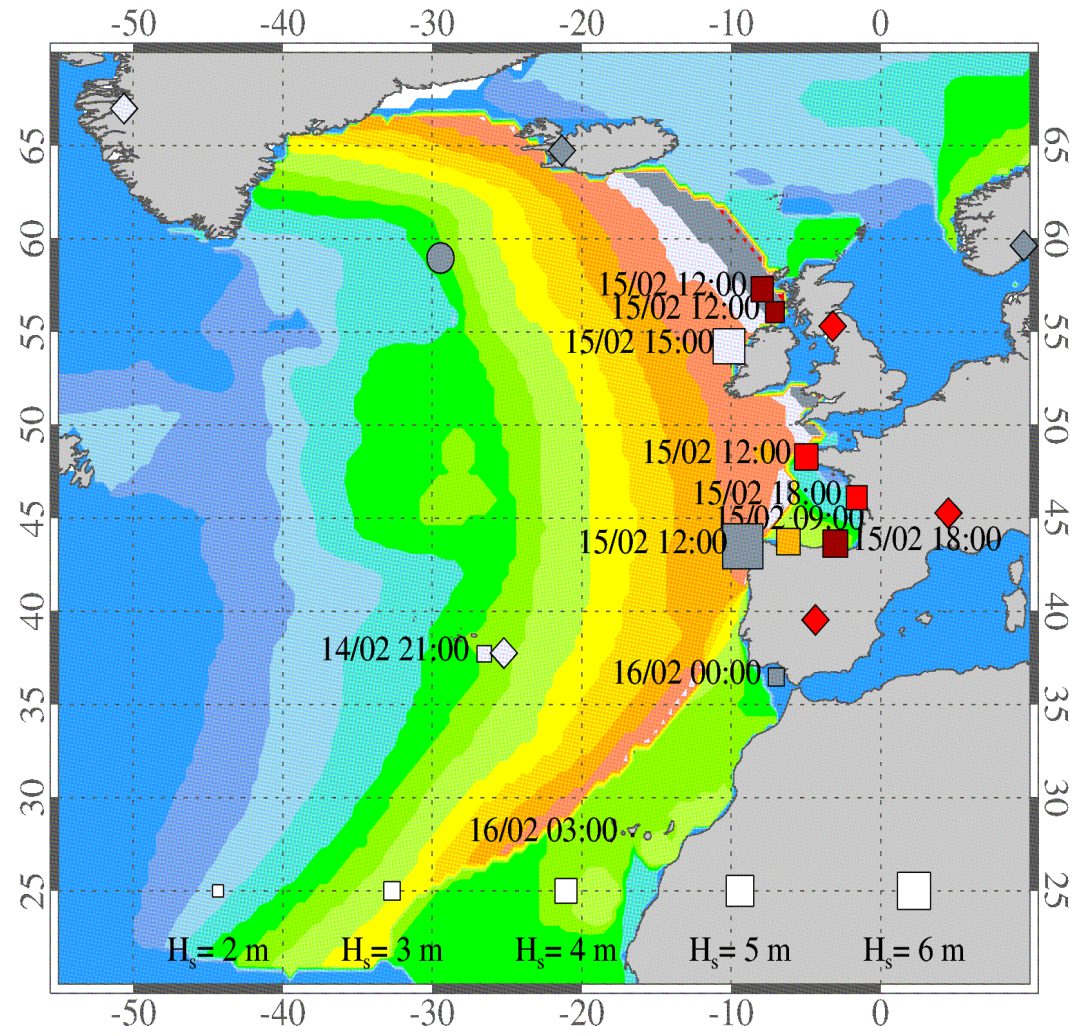

Peak period (s)
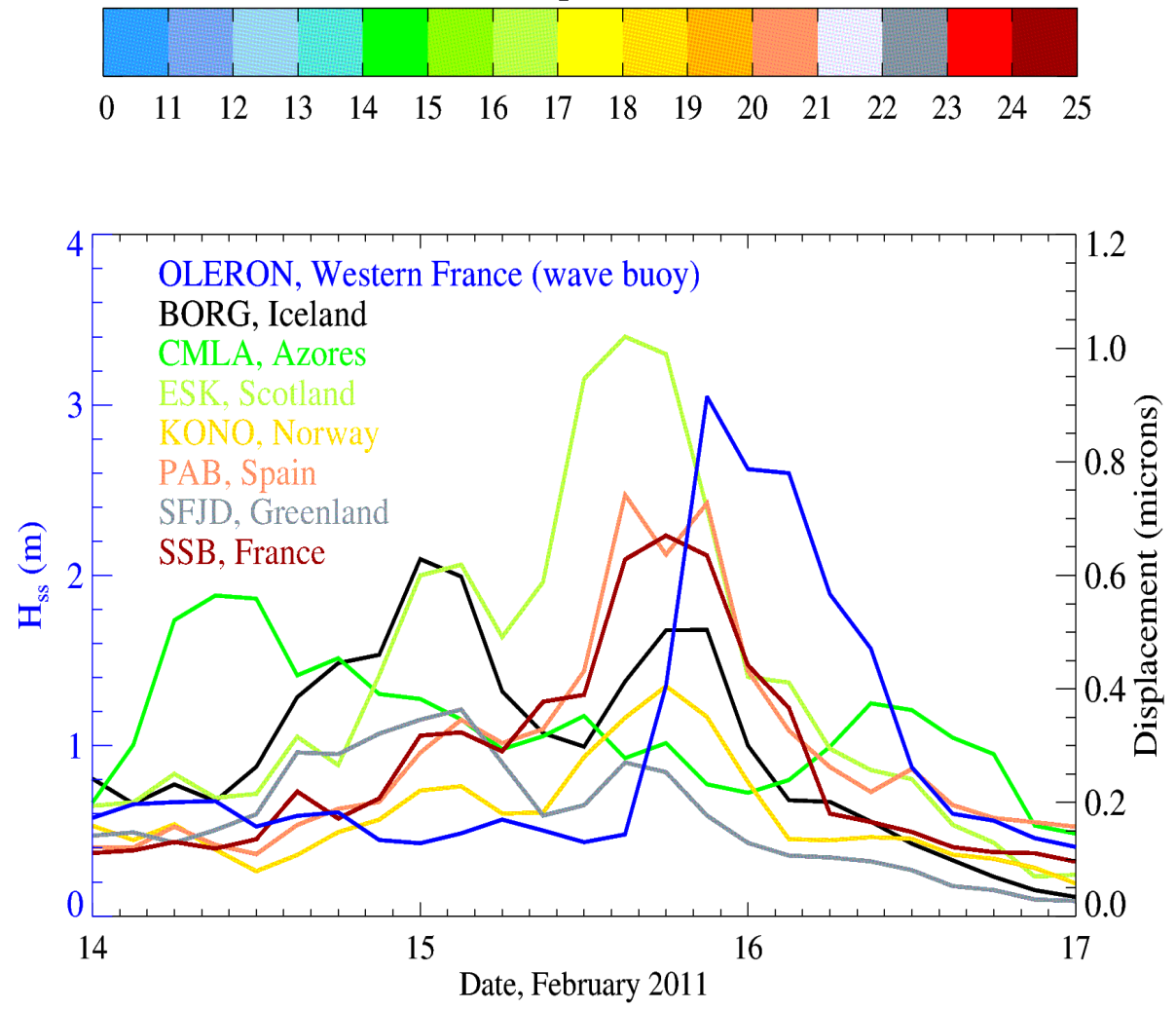

Figure 5. Top: Peak periods of the swell field: as calculated by WW3; from SAR observations; from 
wave buoy data; and from seismic buoy data. The background shows the output from the model at

$36512 \mathrm{Z}$ on the $15^{\text {th }}$, as the longest swells were encroaching on the west coast of Scotland. The square symbols represent the wave buoy data, the size of the symbol signifying the $\mathrm{H}_{\mathrm{s}}$ at the time of the maximum peak period observed and the color signifying the value of the peak period at this time. Beside each symbol is printed the time of arrival of the maximum peak period at each buoy. The circle gives the location of the SAR observations and diamond symbols represent the seismic

370 stations, also colored according to the peak periods observed.

Bottom: Time series of the 3 hour median of the vertical ground displacement variance averaged over 20 minutes, from several stations around the North Atlantic, from February $14^{\text {th }}$ to $17^{\text {th }}$. A timeseries of $\mathrm{H}_{\mathrm{s}}$ from a buoy (OLERON) located off the west coast of France is also shown. 


\section{Supplementary Information}

\section{Altimetric observations at high wave heights}

390 While estimates of $\mathrm{H}_{\mathrm{s}}$ at high sea-states are considered to be relatively robust, altimeters are neither designed nor calibrated for such large values. Here, however, the lack of evidence of saturation errors in the sensor waveform data, the consistency of the along-track patterns in the full $20 \mathrm{~Hz}$ data and the low $1 \mathrm{~Hz}$ standard deviation $(1.46 \mathrm{~m})$ all give a measure of confidence in these measurements. This is supported by the consistency between the very high waves and the long

395 swells which is presented in this study. In general $\mathrm{H}_{\mathrm{s}}$ measurements from altimeters are calibrated using buoy comparisons and inter-altimeter comparisons (Queffeulou 2004). Recent analysis of Jason-2 observations (Queffeulou and Croizé-Fillon 2010) indicates that a slight linear correction to $H_{s}$ should be applied, which would give a maximum value of $20.4 \mathrm{~m}$ rather than $20.1 \mathrm{~m}$ on the $14^{\text {th }}$ February. As this correction was estimated using very few buoy observations between $8 \mathrm{~m}$ and $12 \mathrm{~m}$

400 and none above $12 \mathrm{~m}$, the very high altimeter $\mathrm{H}_{\mathrm{s}}$ values are not directly validated, and estimation of the error in the measurement is difficult.

\section{Discussion of high wind speed retrieval from satellites}

Calibration at high wind speeds is one of the goals of the "International Ocean Vector Winds

405 Science Team" and performing cross-calibration for different satellite sensors with reference in situ data is an active topic of research. The comparison of the winds in Quirin up to hurricane-force between the altimeter and radiometer onboard Jason-1 and Envisat and the ASCAT scatterometer shows that the gale-, storm- and hurricane-force wind scales can be consistently estimated (see also Quilfen et al., 2011). The ultimate goal of having accurate measurements of high wind speeds from 410 sensors operating at different resolutions and on different principles, however, is a topic requiring considerable further research. Satellite-based high wind speed retrievals are difficult to obtain and 
the errors associated with the measurements are difficult to characterize for three main reasons discussed in Quilfen et al. (2010) and outlined below.

\section{1) Saturation at high wind speed.}

Using aircraft data, Fernandez et al. (2006) found that active measurements of the radar crosssection (RCS) can saturate with increasing wind speed and the RCS may even decrease beyond a given wind speed value. This behavior depends on the instrument characteristics such as the wavelength, polarization and incidence angle. The high incidence angles and horizontal polarization of the QuikSCAT scatterometer makes it more sensitive at high winds than the ASCAT instrument. Passive radiometric measurements of brightness temperatures is not affected as much by the issue of saturation (Quilfen et al., 2007; Reul et al., 2010), but the coarser resolution of satellite-based radiometers is not ideal for high wind speed retrievals.

\section{2) Calibration / validation issues.}

The usual specifications for a satellite instrument designed to observe winds is an accuracy of $2 \mathrm{~m} / \mathrm{s}$ and 20 degrees for winds up to $24 \mathrm{~m} / \mathrm{s}$. Very few reliable reference data are available beyond that threshold, equivalent to storm-force winds, for calibration of the instruments' geophysical model functions (GMF), so errors are likely to be greater. For example, the ASCAT GMF has been shown

430 to overestimate the RCS sensitivity at high wind speeds when compared with QuikSCAT high winds, resulting in underestimation of high winds (Soisuvarn et al., 2009). This is common knowledge among operational forecasters and is often mentioned in the Mariner Weather Log publications. On the other hand, although the QuikSCAT winds are sometimes considered a 'reference' measurement, as the GMF has been tuned to passive radiometer measurements whose

435 sensitivity to high winds does not saturate, comparisons with well-calibrated platform measurements have shown that they can, in fact, overestimate winds (with a mean positive bias of 3 
$\mathrm{m} / \mathrm{s}$ above $25 \mathrm{~m} / \mathrm{s}$, as shown by Cardone et al., 2009). Validation of the OceanSat-2 scatterometer to refine its GMF in high wind speeds is currently underway.

\section{3) Representativity of the Geophysical Model Function (GMF)}

Satellite sensors which are sensitive to surface turbulent wind stress are calibrated to equivalent neutral winds due to the paucity of stress observations (Bourassa and Weissman, 2008) and the effect of atmospheric stability on the GMF is effectively ignored. Other geophysical effects, such as the surface current and the degree of development of the sea state can also impact the surface stress and modify the measured RCS for a given neutral wind speed, but are not accounted for in the GMF. In stormy conditions the sea maturity is very variable and the retrieved satellite winds can have errors of several m/s as a result (Quilfen et al., 2001; Plagge et al., in review 2012).

\section{Data}

\section{Wave buoy processing}

1-D spectra from the buoys were averaged over periods of either 2 or 3 hours, depending on the noise level of the spectra. The spectra were partitioned using the 1-D algorithm proposed by Portilla et al. (2009), which removes partitions above a certain frequency threshold, those with low total energy, those spanning few spectral bins and those which fall between two other peaks which both

455 have higher energy. The swell was identified using the ratio between the peak energy of a partition and that of a Pierson-Moskovitz spectrum at the same frequency (Pierson and Moskowitz 1964). When this ratio is less than one, the partition is considered to be swell rather than wind sea. The peak at the lowest frequency was taken as that emanating from the Quirin storm, as directional information was not available for most buoys.

\section{WW3 model runs}


The numerical model hindcasts were run on a quasi-global grid, with a resolution of $0.5^{\circ}$ in latitude $\left(79.5^{\circ} \mathrm{S}\right.$ to $\left.79.5^{\circ} \mathrm{N}\right)$ and longitude $\left(-180^{\circ} \mathrm{E}\right.$ to $\left.180^{\circ} \mathrm{W}\right)$. The model numerical schemes are described by Tolman (2008), including third order schemes with garden-sprinkler correction (Tolman 2002), subgrid island and iceberg blocking (Ardhuin et al. 2011a; Tolman 2003). The parameterizations combine the Discrete Interaction Approximation (Hasselmann et al. 1985), a wind-wave generation term adapted from Janssen (1991, see Ardhuin et al. (2010) for the adjustment details) and dissipation parameterizations (Ardhuin et al. 2010). The model uses 24 directions and 32 frequencies $(0.037-0.72 \mathrm{~Hz})$ In the cases shown here, the hindcast was run from December $1^{\text {st }} 2010$ until February $28^{\text {th }} 2011$, with output every 3 hours. Forcing was provided by NCEP analysis winds corrected globally by a $10 \%$ factor.

\section{Seismic station analysis}

Seismic noise at different frequencies has been correlated with different types of generation mechanisms due to waves. Waves interacting with the shore, for example, produce a modest primary peak, at the same frequency as the waves, typically in the $0.05-0.1 \mathrm{~Hz}$ frequency band (Hasselmann 1963; Haubrich et al. 1963). Non-linear interaction between waves having similar frequencies and moving in almost opposite directions produces pressure perturbations at the ocean surface that excite seismic Rayleigh waves in the ocean and crust waveguide with frequencies double that of the interacting waves (Longuet-Higgins 1950). This phenomenon yields a stronger secondary peak in the $0.1-0.3 \mathrm{~Hz}$ frequency band. This type of secondary micro-seismic generation can be found inside storms. It can also result from wave reflection at the shore or from the encounter of two swells or a swell and a wind sea that may come from the same or from different sources (Ardhuin et al. 2011b). Here, the 3-hourly and the daily medians of the vertical ground

485 variance were calculated from filtered spectra for the February 2011 study and 15-year climatology, respectively. 


\section{References}

Ardhuin, F. and Coauthors, 2010: Semi-empirical dissipation source functions for wind-wave models: part I, definition, calibration and validation. J. Phys. Oceanogr., 40, 1917-1941.

Ardhuin, F., J. Tournadre, P. Queffelou, and F. Girard-Ardhuin, 2011a: Observation and parameterization of small icebergs: drifting breakwaters in the Southern Ocean. Ocean Modelling, 39, 405-410, doi:10.1016/j.ocemod.2011.03.004.

Ardhuin, F., E. Stutzmann, M. Schimmel, and A. Mangeney, 2011b: Ocean wave sources of seismic noise. J. Geophys. Res., 116, C09004, doi:10.1029/2011JC006952.

Bourassa M. A., and D. E. Weissman, 2008: The Influence of Air Density on Scatterometer Retrievals of Surface Turbulent Stress. IEEE International Symposium on Geoscience and Remote Sensing, Boston.

Cardone V. J., A. T. Cox, M. A. Morrone, and V. R. Swail, 2009: Satellite Altimeter Detection of Global Very Extreme Sea States (VESS). 11th International Workshop on Wave Hindcasting and Forecasting, Halifax, October 19-23.

Fernandez, D. E., J. R. Carswell, S. Frasier, P. S. Chang, P. G. Black, and F. D. Marks, 2006: Dualpolarized $\mathrm{C}$ - and $\mathrm{Ku}$-band ocean backscatter response to hurricane-force winds, J. Geophys. Res., 111, C08013, doi:10.1029/2005JC003048.

Hasselmann, K., 1963: A statistical analysis of the generation of microseisms. Rev. of Geophys., 1, $177-210$.

Hasselmann, S., K. Hasselmann, J. H. Allender, and T. P. Barnett, 1985: Computation and parameterizations of the nonlinear energy transfer in a gravity-wave spectrum. Part II: Parameterizations of the nonlinear energy transfer for application in wave models. $J$. Phys. Oceanogr., 15, 1378-1391.

Haubrich, R. A., W. H. Munk, and F. E. Snodgrass, 1963: Comparative spectra of microseisms and swell. Bull. Seism. Soc. Am., 47, 111-127. 
Janssen, P. A. E. M., 1991: Quasi-linear theory of wind wave generation applied to wave forecasting. J. Phys. Oceanogr., 21, 1631-1642.

Longuet-Higgins, M. S., 1950: A theory of the origin of microseisms. Phil. Trans. Roy. Soc. London $A, \mathbf{2 4 3}, 1-35$.

Pierson, Jr, W. J., and L. Moskowitz, 1964: A proposed spectral form for fully developed wind seas based on the similarity theory of S. A. Kitaigorodskii. J. Geophys. Res., 69, 181-190.

Plagge, A. M., D. Vandemark, and B. Chapron, 2012: The impact of ocean currents on scatterometer-derived surface winds, J. Ocean. Atm. Tech., in review.

Portilla, J., F. O. Torres, and J. Monbaliu, 2009: Spectral partitioning and identification of wind sea and swell. J. Atmos. Ocean Technol., 26, 107-122.

Queffeulou, P., 2004: Long Term Validation Of Wave Height Measurements From Altimeters. Marine Geodesy, 27, 495-510.

Queffeulou, P., and D. Croizé-Fillon, cited 2010: Global altimeter SWH data set, Version 7. [Available online at $\mathrm{ftp}: / / \mathrm{ftp}$. ifremer.fr/ifremer/cersat/products/swath/altimeters/waves/documentation/altimeter wave_merge_7.0.pdf]

Quilfen Y., B. Chapron, and D. Vandemark, 2001: The ERS scatterometer wind measurement accuracy: evidence of seasonal and regional biases. J. Atmos. Oceanic Tech., 18, 1684-1697.

Quilfen, Y., C. Prigent, B. Chapron, A. A. Mouche, and N. Houti, 2007: The potential of QuikSCAT and WindSat observations for the estimation of sea surface wind vector under severe weather conditions, J. Geophys. Res., 112, C09023, doi:10.1029/2007JC004163.

Quilfen, Y., B. Chapron, and J. Tournadre, 2010: Satellite microwave surface observations in tropical cyclones, Mon. Weather Rev., 138, 421-437, doi:10.1175/2009MWR3040.1.

Quilfen, Y., D. Vandemark, B. Chapron, H. Feng, and J. Sienkiewicz, 2011: Estimating gale to hurricane force winds using the satellite altimeter, J. Atmos. Oceanic Technol., 28, 453-458, 
doi:10.1175/JTECH-D-10-05000.1.

Reul N., J. Tenerelli, B. Chapron, D. Vandemark, Y. Quilfen, and Y. Kerr, 2010: SMOS satellite Lband radiometer: A new capability for ocean surface remote sensing in hurricanes. $J$. Geophys. Res., 117, C02006, doi:10.1029/2011JC007474.

Soisuvarn S., Z. Jelenak, P. S. Chang, and Q. Zhu, 2009: The Development of a C-Band Advanced Scatterometer (ASCAT) Geophysical Model Function at NOAA/NESDIS. NASA Ocean Vector Wind Science Team Meeting, Boulder, Colorado, 18 - 20 May.

Tolman, H. L., 2002: Alleviating the garden sprinkler effect in wind wave models. Ocean Modelling, 4, 269-289.

Tolman, H. L., 2003: Treatment of unresolved islands and ice in wind wave models. Ocean Modelling, 5, 219-231.

Tolman, H. L., 2008: A mosaic approach to wind wave modeling. Ocean Modelling, 25, 35-47, doi:10.1016/j.ocemod.2008.06.005. 


\begin{tabular}{|l|l|l|l|l|l|l|}
\hline Buoy (WMO code & Institute & Country & Longitude & Latitude & Maximum peak & $\mathbf{H}_{\text {s }}$ at time of \\
or ID) & & & & & peak period (m) \\
\hline 13130 & Puertos del Estado & Spain & -15.82 & 28.18 & 20 & 3 \\
\hline 62024 & Puertos del Estado & Spain & -3.03 & 43.63 & 25 & 4.5 \\
\hline 62025 & Puertos del Estado & Spain & -6.17 & 43.73 & 20 & 4.4 \\
\hline 62047 & ${ }^{\text {CEFAS }}$ & UK & -7.06 & 56.06 & 25 & 3.4 \\
\hline 62048 & ${ }^{1}$ CEFAS & UK & -7.91 & 57.29 & 25 & 4 \\
\hline 62069 & Ifremer & France & -4.97 & 48.29 & 23.5 & 4.4 \\
\hline 62083 & Puertos del Estado & Spain & -9.22 & 43.48 & 22.2 & 6.6 \\
\hline 62085 & Puertos del Estado & Spain & -6.97 & 36.48 & 22.2 & 2.9 \\
\hline Belmullet & Marine Institute & Ireland & -10.15 & 54.23 & 21.1 & 5.7 \\
\hline Oléron & SHOM & France & -1.59 & 46.11 & 23.5 & 3.8 \\
\hline Ponta Delgada & PAC-M & Portugal & -25.72 & 37.73 & 21.1 & \\
\hline
\end{tabular}

Table S.1 Information on wave buoys shown in figure 5 showing buoy positions, values of peak periods and significant wave heights at the time of the maximum peak period observed from 1-D 490 spectra. ${ }^{1}$ Centre for Environment, Fisheries and Aquaculture Science, ${ }^{2}$ Universidade dos Açores, CLIMAAT-MacSIMAR. 